\section{PERTANGGUNGJAWABAN ATAS \\ PENGRUSAKAN DAN PENCEMARAN \\ LINGKUNGAN LAUT DI LINTAS BATAS NEGARA \\ MENURUT INSTRUMEN HUKUM \\ INTERNASIONAL ${ }^{1}$ \\ Oleh : Abigail A. J. Junginger ${ }^{2}$ \\ Harold Anis ${ }^{3}$ \\ Thor Bangsaradja Sinaga ${ }^{4}$}

\begin{abstract}
ABSTRAK
Tujuan dilakukannya peneltian ini adalah untuk
\end{abstract} mengetahui bagaimana ketentuan hukum dalam kaitannya dengan pencemaran dan pengrusakan lingkungan laut lintas batas Negara dan bagaimana upaya negara meminta pertanggung jawaban atas pengrusakan dan pencemaran lingkungan laut di lintas batas Negara. Dengan menggunakan metode peneltian yuridis normatif, disimpulkan: 1 . Indonesia mengambil tindakan tegas dalam kasus perusakan dan pencemaran lingkungan laut yang terjadi di jalur lintas batas negaranya. Dalam kasus ini Indonesia berhak mendapat kompensasi ganti kerugian dari pelaku pencemaran lingkungan laut yang terjadi wilayah perairan Indonesia, bahkan dalam ketentuan hukum internasional juga sudah diatur mengenai setiap Negara yang melakukan perbuatan melanggar aturan hukum internasional harus mendapatkan sanksi dan dapat memberikan ganti kerugian terhadap Negara yang menjadi dampak dari pencemaran lingkungan laut tersebut. Dalam kasus seperti demikian sangatlah penting untuk mendapatkan perhatian penuh dari pihak pemerintah internasional untuk segera menangani kasus tersebut agar supaya Negara yang menjadi pelaku pencemaran lingkungan laut itu langsung membayar kompensasi ganti rugi kepada Negara yang menjadi korban pencemaran lingkungan lautnya. 2. Upaya Negara Indonesia dalam meminta pertanggungjawaban atas perusakan dan pencemaran lingkungan laut di wilayah yurisdiksi Negara Indonesia adalah dengan cara melakukan pengajuan kepada pemerintah internasional dalam hal ini melalui pengadilan

\footnotetext{
${ }^{1}$ Artikel Skripsi

2 Mahasiswa pada Fakultas Hukum Unsrat, NIM. 17071101034

3 Fakultas Hukum Unsrat, Magister Ilmu Hukum

${ }^{4}$ Fakultas Hukum Unsrat, Magister IImu Hukum
}

internasional yang menangani kasus atas perusakan dan pencemaran lingkungan laut di lintas batas Negara. Indonesia mempunyai kewenangan sebagai Negara pantai untuk dapat mengajukan ganti rugi kepada Negara pelaku pencemaran itu menurut hukum nasionalnya. Agar supaya dalam kasus ini benar-benar pihak merupakan pelaku pencemar dapat mematuhi setiap prosedur yang berlaku baik dalam hukum internasional maupun hukum nasional di wilayah yurisdiksi negara yang menjadi korban pencemaran tersebut.

Kata kunci: Pertanggungjawaban, Pengrusakan dan Pencemaran, Lingkungan Laut, Lintas Batas Negara, Instrument Hukum Internasional.

\section{PENDAHULUAN}

\section{A. Latar Belakang Masalah}

Masalah lingkungan yang marak dibahas dalam lingkup internasional adalah trans frontier pollution atau yang sering dikenal dengan nama pencemaran lintas batas. Salah satu contoh kasus pencemaran lintas batas di wilayah laut adalah adanya tabrakan kapal yang kemudian menumpahkan minyak mentah ke laut. Seperti yang terjadi pada tahun 2015 antara kapal Alyarmouk dari Libya dan MV Sinar Kapuas dari Singapura. Tabrakan tersebut terjadi di perbatasan Indonesia dan Singapura yang menyebabkan tercemarnya perairan Indonesia akibat tumpahan minyak di sekitar Pulau Bintan. Peristiwa tersebut tepatnya terjadi di perairan sekitar 11 mil laut timur Pedra Branca, sebuah pulau terpencil yang merupakan titik paling timur di Singapura. Tumpahan minyak ini disebabkan oleh tabrakan yang terjadi antara kapal MT Alyarmouk dari Libya dengan kapal MV Sinar Kapuas yang merupakan milik pemerintah Singapura. Tabrakan tersebut menyebabkan robeknya lambung kapal Alyarmouk yang sedang dalam perjalanan menuju Tiongkok dan menumpahkan minyak bertipe Madura Crude Oil. Diperkirakan jumlah minyak yang tumpah adalah sebesar 4.500 ton minyak mentah.

Indonesia pun mendapat imbas dari peristiwa tersebut. Pulau Bintan yang merupakan salah satu pulau terluar Indonesia yang berbatasan dengan Singapura, terkena rembetan dari minyak tersebut di sebelah utara pulau. Pulau Bintan adalah salah satu pulau 
yang paling terancam, pasalnya lokasi kecelakaan hanya 18,6 mil dari pulau Bintan. Tumpahan minyak ini dikhawatirkan akan menimbulkan efek rusaknya ekosistem laut yang berada di sekitar pulau Bintan.

Kasus di atas sebenarnya Indonesia berhak mengajukan upaya hukum internasional atas pengrusakan dan pencemaran tumpahan minyak di yurisdiksi wilayah kedaulatan laut Indonesia sebagaimana ketentuan dalam kesepakatan internasional baik secara pertanggungjawaban hukumnya dan juga instrument internasional yang terlibat dalam penyelesaian antar Negara yang bersengketa. Untuk itu sangat penting mengetahui secara mendalam mengenai bagaimanakah hukum internasional memberikan perlindungan terhadap kelestarian lingkungan laut. Selain itu tindakan-tindakan apakah yang seharusnya ditempuh oleh para pihak yang terlibat dalam sengketa pencemaran lintas batas Indonesia yang dilakukan oleh Singapura pada kasus tumpahan minyak akibat dari tabrakan kapal tersebut, sehingga Penulis mengambil judul Pertanggungjawaban Atas Pengrusakan Dan Pencemaran Lingkungan Laut Di Lintas Batas Negara Menurut Instrumen Hukum Internasional.

\section{B. Rumusan Masalah}

1. Bagaimanakah ketentuan hukum dalam kaitannya dengan pencemaran dan pengrusakan lingkungan laut lintas batas negara?

2. Bagaimanakah upaya negara meminta pertanggung jawaban atas pengrusakan dan pencemaran lingkungan laut di lintas batas negara?

\section{Metode Penelitian}

Metode penelitian yang digunakan pada penulisan ini adalah metode penulisan yuridis normatif, dimana penelitian melalui metode ini merupakan penelitian yang mengkaji studi dokumen berupa literatur dan berbagai buku sebagai sumber dalam penulisan skripsi ini. Penelitian dalam metode ini menggunakan analisis kualitatif sebagai dasar untuk menjelaskan data-data yang ada dengan katakata bukan dengan angka-angka.

\section{PEMBAHASAN}

A. Ketentuan Hukum dalam kaitannya dengan Pencemaran dan Pengrusakan Lingkungan Laut Lintas Batas Negara

Lintas berarti navigasi melalui laut teritorial untuk keperluan melintas laut tanpa memasuki perairan pedalaman atau singgah di tempat berlabuh di tengah laut (roadstad) atau fasilitas pelabuhan di luar perairan pedalaman, atau berlalu ke atau dari perairan pedalaman atau singgah di tempat berlabuh di tengah laut atau fasilitas pelabuhan tersebut.

Jenis lintas yang di atur dalam UNCLOS 1982 yaitu lintas damai, lintas alur laut kepulauan dan lintas transit. Akan tetapi berdasarkan Pasal 47 ayat (6) dan Pasal 51 UNCLOS 1982, Negara kepulauan seperti halnya Indonesia diminta untuk menghormati hak Negara tetangga terkait dengan kegiatan/kepentingan yang sah (legitimate) di perairan kepulauannya. Salah satu kegiatan yang sah dimaksud dapat berupa lintas pelayaran dan penerbangan. ${ }^{5}$

Salah satu bentuk gagasan yang telah banyak mempengaruhi pemikiran dampak lingkungan lintas batas adalah Rekomendasi OECD tentang Principle Concerning Transfrontier Pollution, yang ditetapkan pada tanggal 14 November 1974. Beberapa pokok pikiran dalam rekomendasi tersebut di uraikan di bawah ini untuk bahan perbandingan.

\section{Hak lintas damai}

Pasal 3 sampai dengan 7 menegakkan pengertian "hak lintas damai" (innocent passage) kapal-kapal asing melalui laut teritorial. Pasal-pasal ini selanjutnya menegaskan hak-hak dan kewajiban, baik dari pada Negara pantai maupun kapal yang lewat. Pasal 3 ayat 1 memuat ketentuan mengenai pengertian dari pada lintas (passage) dengan menentukan bahwa lintasan adalah berlayar melalui laut teritorial, baik untuk melewati tanpa masuk ke dalam perairan pedalaman maupun untuk masuk ke perairan pedalaman demikian pula menuju laut bebas setelah meninggalkan laut pedalaman.

Ketentuan bahwa Negara pantai mempunyai kedaulatan atas laut teritorial-nya, sebagai bagian dari pada wilayahnya, menimbulkan

\footnotetext{
${ }^{5}$ Mangisi Simanjuntak, 2018, Konvensi PBB 1982 Tentang Hukum Laut Makna dan Manfaatnya Bagi Bangsa Indonesia, Mitra Wacana Media, Jakarta, hal. 67.
} 
beberapa masalah bertalian dengan kapal-kapal asing yang berada dalam laut wilayah dalam lintas damai. Dalam hal sebuah kapal berada dalam laut wilayah, maka pada waktu yang bersamaan berlaku dua yurisdiksi terhadap kapal tersebut yakni:

1) Yurisdiksi Negara pantai yang mempunyai kedaulatan atas laut wilayah dan

2) Yurisdiksi Negara di bawah bendera mana kapal itu berlayar.

Secara sepintas lalu dan sederhana ada dua kemungkinan untuk memecahkan persoalan persaingan kompetensi atau yurisdiksi antara Negara pantai dan Negara bendera kapal ini yakni dengan memenangkan yang satu atas yang lain. Dimenangkannya yurisdiksi Negara pantai berarti bahwa kapal asing yang memasuki laut wilayah suatu Negara tunduk sepenuhnya pada yurisdiksi Negara pantai, juga untuk penuntutan soal-soal criminal dan perdata. ${ }^{6}$

Hak-hak Negara pantai terhadap penanggulangan pencemaran (injury) di luar wilayahnya (beyond national jurisdiction) berdasarkan hukum internasional umum (general international law) didasarkan pada doktrin self-help, self-preservation, dan selfdefence. Apabila di kaji batasan hukum atas pengertian di atas dari pelbagai komentar dan argumentasi para penulis hukum, sukar di peroleh batasan yang jelas antara ketiga pengertian di atas, kalau tidak dapat di katakan kabur.

Hak Negara pantai sebagaimana di sebut di atas, kemudian menjadi ketentuan hukum yang dimuat dalam konvensi IMCO 1969 tentang Public Law Convention (konsep intervensi Negara pantai di laut lepas atas kecelakaan oleh pencemaran minyak dari kapal). Konvensi ini memberikan wewenang kepada Negara mengambil tindakan to prevent, mitigate or eliminate grave and imminent danger to their coastline of related interests from pollution atau bahaya yang disebabkan oleh minyak following upon a maritime causality or acts related to such causality. Berdasarkan konvensi ini, hak Negara berpusat pada:

- Bahaya dari pencemaran laut oleh minyak saja.

6 Ibid, hal. 66-67.
- Mengharuskan adanya pemberitahuan dan konsultasi (notification and consultation) terlebih dahulu;

- Berdasarkan kriteria proportionate terhadap kerusakan atau kerugian; dan

- Keharusan membayar ganti rugi (kompensasi) apabila tindakan Negara pantai melebihi kepatutan yang dianggap perlu (reasonable necessary) bagi penanggulangan pencemaran sehingga menimbulkan kerugian pada pelaku pencemar. Prinsip proportionate ini sebenarnya telah ada pada prinsip hukum kebiasaan umum (the general customary law principles). Keharusan membayar kompensasi atas tindakan yang berlebihan dari Negara pantai (excessive measure) telah di temukan dalam hukum kebiasaan internasional (customary international law). ${ }^{7}$

Perjanjian Internasional

Dalam pengertian umum dan luas, perjanjian internasional yang dalam bahasa Indonesia disebut juga persetujuan, traktat, ataupun konvensi, adalah :

Kata sepakat antara dua atau lebih subyek hukum internasional mengenai suatu obyek atau masalah tertentu dengan maksud untuk membentuk hubungan hukum atau melahirkan hak dan kewajiban yang diatur oleh hukum internasional. ${ }^{8}$

Berdasarkan pengertian tersebut maka dapat dijabarkan beberapa unsur atau kualifikasi yang harus terpenuhi suatuu perjanjian dapat disebut perjanjian internasional, yaitu:

a. Kata Sepakat,

b. Subyek-subyek hukum.

c. Berbentuk tertulis,

d. Obyek tertentu,

e. Tunduk pada atau diatur oleh hukum internasional. $^{9}$

Perjanjian internasional ditinjau dari segi jumlah Negara-negara yang menjadi pihak atau pesertanya.

\footnotetext{
7 Ibid, hal. 212-213.

8 I Wayan Parthiana, 2018, Hukum Perjanjian Internasional Bagian 1 Edisi Revisi, Mandar Maju, Bandung, hal. 12.

9 Ibid, hal. 14.
} 
Ditinjau dari segi jumlah Negara-negara yang menjadi pihak atau peserta pada suatu perjanjian internasional, sudah lazim dibedakan antara :

a. Perjanjian internasional bilateral, yaitu suatu perjanjian internasional yang pihak-pihak atau Negara peserta yang terikat dalam perjanjian tersebut adalah hanya dua pihak atau dua Negara saja.

b. Perjanjian internasional multilateral, yaitu suatu perjanjian internasional yang pihak-pihak atau Negara-negara yang menjadi peserta pada perjanjian itu lebih dari dua Negara. ${ }^{10}$

Dalam rangka pengembangan prinsip ini, arti pencemaran dirumuskan sebagai:

"the introduction by man, directly or indirectly, of substances or energy into the environment resulting in deleterious effects of living resources and ecosystems, and impair or interfere with amenities and other legitimate uses of the environment."

Pengertian pencemaran dalam arti, kecuali di tetapkan lain, dimaksudkan dengan pencemaran yang berasal dari suatu Negara yang menimbulkan akibat di Negara-negara lain. ${ }^{11}$

\section{Penerapan Prinsip Nondiskriminasi}

Terhadap dampak lingkungan lintas batas dikenakan prinsip nondiskriminasi. Berdasarkan prinsip nondiskriminasi:

- Para pelaku pencemar yang menimbulkan dampak lintas batas harus dikenakan ketentuan yang sama atau lebih berat dari ketentuan yang berlaku di Negara asal si pelaku pencemar sendiri, dengan memperhatikan keadaan khusus lingkungan dan pemanfaatan kawasan tersebut.

- Penerapan tanggung jawab terhadap baku mutu pada dampak lingkungan yang bersifat lintas batas nasional tidak boleh melampaui baku mutu di Negara asal pencemar, seberapa mungkin dengan memperhatikan keadaan lingkungan Negara terkena pencemaran. ${ }^{12}$
Ketentuan hukum dalam mengatasi pencemaran dan pengrusakan lingkungan laut di lintas batas Negara sudah di atur dalam UNCLOS 1982 mengenai Perlindungan dan pelestarian lingkungan laut dalam Bab XII Pasal 192-237, yang terdiri atas beberapa aspek yaitu: kewajiban umum Negara-negara terhadap perlindungan dan pelestarian lingkungan laut (Pasal 192-193), kewajiban Negara terhadap penanggulangan pencemaran (Pasal 194-196), kerjasama internasional mengenai perlindungan dan pelestarian lingkungan laut (Pasal 197-201), bantuan teknik (Pasal 202-203), monitoring dan analisa lingkungan (Pasal 204-206), pembuatan peraturan perundang-undangan disertai penegakan hukumnya (Pasal 207-234), tanggung jawab dan ganti rugi (Pasal 235), hak kekebalan (Pasal 236), dan kewajiban lain berdasarkan konvensi lain (Pasal 237). ${ }^{13}$

Dalam melaksanakan amanat UNCLOS 1982 Indonesia telah mengeluarkan beberapa peraturan perundang-undangan, baik yang berbentuk Undang-undang, Peraturan Pemerintah, maupun yang berbentuk Peraturan Menteri. Selain itu Indonesia juga telah melakukan beberapa perjanjian Internasional di bidang perlindungan lingkungan laut, baik secara global, regional, multilateral, dan bilateral. Bahkan Sejak tahun 1985 Indonesia telah meratifikasi Konvensi Hukum Laut Internasional (UNCLOS 1982) melalui UndangUndang Nomor 17 Tahun 1985 tentang pengesahan United Nations Convention on the law of the sea (Konvensi Perserikatan BangsaBangsa tentang Hukum Laut 1982). Dengan ratifikasi tersebut, Indonesia harus menindak lanjuti berbagai hak dan kewajiban yang berasal dari UNCLOS karena Indonesia termasuk negara pihak dari Konvensi Hukum Laut Internasional tersebut. Dengan demikian, kedaulatan dan hak berdaulat serta yuridiksi Republik Indonesia atas ruang perairan serta segala kekayaan alam yang terdapat di permukaan laut dan udara diatasnya, di dalam kolom air serta di dasar laut dan tanah di bawahnya telah diakui oleh Hukum Internasional. Oleh karena itu terbuka peluang seluas-luasnya untuk dimanfaatkan

\footnotetext{
$10 \mathrm{lbid}$, hal. 40.

$11 \mathrm{lbid}$, hal. 205.

$12 \mathrm{lbid}$, hal. 206.
}

13 UNCLOS 1982 
bagi peningkatan kesejahteraan seluruh rakyat Indonesia. ${ }^{14}$

\section{B. Upaya Negara meminta \\ Pertanggungjawaban atas Pengrusakan dan Pencemaran Lingkungan Laut di lintas batas Negara}

Prinsip tanggung jawab Negara dalam sistem dalam sistem hukum nasional

Prinsip tanggungjawab Negara selain mempunyai fungsi eksternal, juga mempunyai fungsi internal, yaitu terhadap warga Negara dari Negara yang bersangkutan. Perbedaan yang signifikan dari bentuk pertanggungjawaban Negara terhadap warga Negara adalah obyek dari penerapan prinsip ini yaitu melibatkan hubungan antara Negara atau pemerintah yang melaksanakan fungsi Negara dengan warga Negara dari Negara yang bersangkutan. ${ }^{15}$

Kedaulatan sebagai sebuah konsep, secara tradisional memiliki pengertian eksternal (keluar) dan internal (ke dalam). Kedaulatan internal adalah anggapan apabila suatu Negara memiliki kewenangan tertinggi di dalam wilayah kekuasaannya. Dalam kaitan dengan pembatasan kekuasaan, menurut Machiavelli, penguasa tidak boleh dibatasi oleh nilai-nilai moral dan tuntutan kebiasaan dalam upayanya untuk mewujudkan kepentingan Negara. Sementara Hobbes hanya menambahkan pembatasan terhadap tiga hak, yakni hak hidup, kebebasan, dan hak tinggal. Sedangkan kedaulatan eksternal adalah kemampuan bagi Negara-negara untuk melakukan hubungan internasional. ${ }^{16}$

Konsep Negara kesejahteraan tidak hanya mencakup deskripsi mengenai sebuah cara pengorganisasiaan kesejahteraan (welfare) atau pelayanan sosial (social services). Melainkan juga sebuah konsep normatif atau sistem pendekatan ideal yang menekankan bahwa setiap orang harus memperoleh pelayanan sosial sebagai haknya. ${ }^{17}$

Sistem hukum menurut Friedman adalah suatu kesatuan yang fungsional yang terdiri dari struktur, substansi dan budaya hukum yang

\footnotetext{
14 UU Nomor 17 Tahun 1985 tentang pengesahan UNCLOS ( Konvensi PBB tentang hukum laut 1982)

$15 \mathrm{lbid}$, hal. 20.

16 Ibid, hal. 21-22.

$17 \mathrm{lbid}$, hal. 29.
}

berlaku di suatu Negara. Dari perkembangan asal-usul Negara dan fungsi Negara yang telah diungkapkan diatas, Indonesia yang secara tersurat dan tersirat mengidentikkan dalam kerangka Negara kesejahteraan, jelas secara normative yuridis mengakui adanya kewajiban bagi Negara untuk menjamin hak-hak fundamental bagi warga negaranya. Dalam sistem hukum nasional, secara substansial dalam pasal-pasal Undang-Undang Dasar 1945 disebutkan bahwa Negara menjamin warga negaranya dalam kedudukan hukum, mempertahankan kehidupan, melanjutkan keturunan, memeluk agama, pendidikan, kesejahteraan, dan menikmati kekayaan alam untuk kemakmuran rakyat. ${ }^{18}$

Prinsip pertanggungjawaban Negara dalam sistem Hukum Internasional

Dalam perkembangannya, hukum internasional sering didefinisikan secara umum, sebagai keseluruhan hukum yang untuk sebagian besar terdiri dari prinsip-prinsip dan kaidah-kaidah perilaku, yang terhadapnya, Negara-negara merasa dirinya terikat untuk mentaati, dan karenanya, benar-benar ditaati secara umum dalam hubungan-hubungan mereka satu sama lain.

Hukum internasional yang juga sering disebut dengan hukum Bangsa-bangsa ini. Pada hakikatnya, menurut Grotius, berada dalam ranah normatif yang mengatur hak dan kewajiban antara entitas yang disebut bangsa atau Negara yang satu dengan Negara bangsa yang lain dalam kancah pergaulan internasional. Perdebatan kemudian muncul dalam melihat hubungan antara hukum bangsabangsa dengan hukum nasional dari suatu bangsa tertentu. Kompleksitas dari hal tersebut akan semakin bertambah pada saat terdapat benturan berupa pertentangan-pertentangan normatif antara kedua hukum tersebut. ${ }^{19}$

Dalam perkembangannya, sebagai konsekuensi logis dari prinsip persamaan dan kedaulatan Negara terdapat dalam ketentuan hukum internasional, adalah pemberian kewenangan bagi tiap Negara untuk dapat menuntut suatu bentuk pertanggungjawaban dari pihak lain dalam hal terjadinya pelanggaran hak suatu Negara. Hal ini kemudian diperkuat

\footnotetext{
18 Ibid, hal. 30-31.
}

$19 \mathrm{lbid}$, hal. 31. 
dengan adagium yang dipopulerkan oleh Grotius pada tahun 1646 yang menyatakan, bahwa pada setiap kesalahan internasional mengakibatkan kewajiban untuk mengembalikan kerugian yang terjadi.

Prinsip pertanggungjawaban Negara dalam metamorfosisnya menjadi salah satu prinsip inti dari hukum internasional. Prinsip ini lalu berkembang sangat pesat setelah era perang dunia. Terdapat beberapa konvensi PBB yang menempatkan subyek hukum Negara sebagai suatu entitas yang dapat diminta pertanggungjawabannya. Bahkan, dalam kondisi tertentu, individupun dapat diminta pertanggungjawabannya. Secara khusus United Nations-pun melalui Komisi Hukum Internasional (International Law Commission), sejak 1949, memusatkan perhatian dengan merumuskan dasar hukum dalam State Responsibility, sehingga dapat mengantisipasi kerugian yang timbul bagi suatu Negara meskipun tanpa adanya perjanjian internasional yang mengikat para pihak Negara bersangkutan. ${ }^{20}$

\section{Bentuk Pertanggungjawaban Negara}

Dalam hal terpenuhinya unsur-unsur suatu tindakan yang termasuk dalam kategori act of state tersebut, maka Negara yang melakukan suatu tindakan dan pelanggaran terhadap kewajiban internasional dipersyaratkan untuk melakukan suatu bentuk pertanggungjawaban secara internasional baik dengan instrumen hukum maupun diplomatik.

Tindakan awal dalam melakukan pertanggungjawaban internasional adalah menghentikan conduct yang menjadi dasar terjadinya kerugian Negara lain dan memastikan tidak mengulang hal yang sama. Ketentuan ini menjadi landasan untuk segera menghentikan tindakan yang merugikan Negara lain dalam waktu sesingkat-singkatnya.

Ketentuan selanjutnya mengatakan bahwa Negara yang menyebabkan kerugian bagi Negara lain karena tindakan internasional yang dilakukannya wajib untuk mengadakan reparasi terhadap Negara yang terkena dampak. Reparasi yang dilakukan meliputi segala kerugian yang timbul baik berupa kerugian material maupun kerugian imaterial. Bentuk reparasi yang dapat dilakukan meliputi restitusi, kompensasi dan juga bentuk pelunasan lainnya, baik secara satu persatu maupun melalui ketiga instrumen sekaligus.

Dalam hal dilakukannya restitusi, Negara penyebab suatu kerugian bagi Negara lain diharuskan untuk mengembalikan keadaan seperti semula selayaknya suatu Negara berjalan dalam keadaan normal. Apabila hal tersebut dianggap tidak memuaskan, maka Negara tersebut juga diharuskan memberikan suatu kompensasi terhadap kerugiaan material yang diperhitungkan dan juga terhadap keuntungan yang diharapkan dari suatu pengelolaan Negara.

Dalam situasi tertentu memungkinkan pula suatu Negara yang menyebabkan injury bagi Negara lain tidak mempunyai kemampuan untuk melakukan suatu pertanggungjawaban secara hukum, baik meliputi restitusi maupun kompensasi. Pada saat demikian, maka ketentuan dalam Draft Articles on Responsibility of State for Internationally Wrongful Acts menetapkan cara terakhir berupa permintaan maaf kepada Negara yang terkena dampak. ${ }^{21}$

Pertanggungjawaban terhadap pencemaran lingkungan

Dalam perkembangan hukum internasional, kewajiban Negara tidak terlepas dari kewajiban untuk tidak melakukan pencemaran dan perusakan lingkungan bagi Negara lain. Terlebih dengan seiring banyaknya perjanjian-perjanjian internasional yang merumuskan kewajiban bagi tiap Negara untuk tidak mencemari dan merusak ekosistem yurisdiksi Negara lain.

Prinsip pertanggungjawaban Negara pun secara tidak langsung telah di absorb dalam beberapa perjanjian lingkungan internasional sebagaimana termuat dalam perumusan Pasal 21 Deklarasi Stockholm 1972.

"State have, in accordance with th Charter of the United Nations and the principles og international law, the sovereign right to exploit their own resources pursuant to their own environmental policies, and the responsibility to ensure that activities within their jurisdiction or control do not cause damage to the environment of other States 
or of areas beyond the limits of nasional jurisdiction"

Hal ini merupakan suatu bentuk penanganan kasus lingkungan yang secara tegas membuat panduan dan akibat hukum dalam proses pengelolaan lingkungan pada tingkat internasional. Walaupun hingga saat ini belum ada satu kasus lingkungan pun yang dituntut dengan landasan dasar hukum di atas, namun paling tidak dengan adanya ketentuan hukum internasional yang mengatur mengenai kriteria dan bentuk pertanggungjawaban Negara terhadap kerugian internasional terhadap semakin hebatnya bentuk pencemaran lingkungan trans-nasional. ${ }^{22}$

\section{PENUTUP}

\section{A. Kesimpulan}

1. Indonesia mengambil tindakan tegas dalam kasus perusakan dan pencemaran lingkungan laut yang terjadi di jalur lintas batas negaranya. Dalam kasus ini Indonesia berhak mendapat kompensasi ganti kerugian dari pelaku pencemaran lingkungan laut yang terjadi wilayah perairan Indonesia, bahkan dalam ketentuan hukum internasional juga sudah diatur mengenai setiap Negara yang melakukan perbuatan melanggar aturan hukum internasional harus mendapatkan sanksi dan dapat memberikan ganti kerugian terhadap Negara yang menjadi dampak dari pencemaran lingkungan laut tersebut. Dalam kasus seperti demikian sangatlah penting untuk mendapatkan perhatian penuh dari pihak pemerintah internasional untuk segera menangani kasus tersebut agar supaya Negara yang menjadi pelaku pencemaran lingkungan laut itu langsung membayar kompensasi ganti rugi kepada Negara yang menjadi korban pencemaran lingkungan lautnya.

2. Upaya Negara Indonesia dalam meminta pertanggungjawaban atas perusakan dan pencemaran lingkungan laut di wilayah yurisdiksi Negara Indonesia adalah dengan cara melakukan pengajuan kepada pemerintah internasional dalam hal ini melalui pengadilan internasional yang menangani kasus atas perusakan dan pencemaran lingkungan laut di lintas batas Negara. Indonesia mempunyai kewenangan sebagai Negara pantai untuk dapat mengajukan ganti rugi kepada Negara pelaku pencemaran itu menurut hukum nasionalnya. Agar supaya dalam kasus ini benar-benar pihak merupakan pelaku pencemar dapat mematuhi setiap prosedur yang berlaku baik dalam hukum internasional maupun hukum nasional di wilayah yurisdiksi negara yang menjadi korban pencemaran tersebut.

\section{B. Saran}

1. Sangatlah diharapkan kedepannya baik dari pemerintah internasional maupun nasional untuk dapat menerapkan dengan baik sanksi terhadap Negara yang menjadi pelaku pencemaran lingkungan laut tersebut. Bahkan dalam hal mengenai aturan senantiasa pemerintah haruslah dengan lebih disiplin dan ketat agar supaya kedepannya jika terdapat kasus yang serupa sudah ada aturan yang jelas menangani kasus perusakan dan pencemaran lingkungan laut yang berada dii jalur lintas batas Negara. Sehingga para pihak yang bersengketa dapat melakukan kembali kerjasamanya dalam bidang perekonomian maupun bidang yang lain melalui jalur laut, bahkan dalam hal ini dari pihak pemerintah harus berperan aktif dalam penerapan sebuah aturan terhadap pelaku pencemaran lingkungan laut di lintas batas Negara.

2. Negara Indonesia telah dengan sangat baik melakukan upaya untuk meminta pertanggungjawaban terhadap pencemaran laut yang terjadi wilayah yurisdiksi negaranya yang diakibatkan oleh adanya tabrakan kapal asing dan menumpahkan minyak ke laut sehingga membuat lautan Indonesia tercemar akibat dari tabrakan kedua kapal asing tersebut. Mengenai ganti rugi dalam kasus ini belum terealisasi secara baik dikarenakan kasus ini hanya mengambil jalan pintas yaitu melalui jalur Negosiasi, padahal jika dicermati dengan baik mengenai kasus ini Indonesia sangatlah 
dirugikan karena minyak yang tumpah ke lautan Negara Indonesia tersebut membuatnya tercemar dan mengganggu kehidupan biota laut bahkan warga masyarakat yang ada di bertempat tinggal wilayah pesisir tempat terjadinya kasus pencemaran lingkungan laut itu. Maka dalam hal ini dibutuhkanlah kerjasama antar masyarakat dan pemerintah baik dari pemerintah internasional maupun nasional untuk dapat menjaga dan melestarikan lingkungan laut bahkan dalam hal mengenai kompensasi ganti kerugiaan pemerintah harus langsung turun tangan agar ketika terjadi lagi kasus yang serupa sudah benar-benar ada campur tangan dari pihak pemerintah internasional dan Negara yang menjadi pelaku pencemaran lingkungan laut tersebut. Sehingga Negara Indonesia yang dalam hal ini terkena dampak akibat dari tabrakan kapal dan menumpahkan minyak ke perairan Indonesia dapat menikmati lautan yang bersih dan bisa kembali melangsungkan kehidupan secara normal.

\section{DAFTAR PUSTAKA}

Bram, Deni, 2008, Hukum Lingkungan Internasional Penerapan Prinsip Tanggung Jawab Negara, Jakarta, Cintya Press.

Erwin, Muhamad, 2019, Hukum Lingkungan Sistem Kebijaksanaan Lingkungan Hidup, edisi revisi II, Bandung, PT Revika Aditama.

Husin, Sukanda, 2016, Hukum Lingkungan Internasional, Jakarta, PT Raja Grafindo Persada.

Kalalo Flora, Pricilla, 2009, Implikasi Kebijaksanaan Reklamasi Pantai \& Laut di Indonesia, buku 2, Manado, LoGoz.

Kalalo Flora, Pricilla, 2016, Hukum Lingkungan, Manado, Unsrat Press.

Kusumaatmadja, Mochtar, 1978, Hukum Laut Internasional, Bandung, Bina Cipta

Mauna, Boer, 2018, Hukum Internasional Pengertian Peranan Dan Fungsi Dalam Era Dinamika Global, Bandung, PT Alumni.
Parthiana, I Wayan, 2018, Hukum Perjanjian Internasional, Bagian 1 Edisi Revisi, Bandung, Mandar Maju.

Sefriani, 2019, Hukum Internasional Suatu Pengantar, Edisi Revisi Kedua, Raja Grafindo Persada, Depok.

Sembiring, Sentosa, 2019, Hukum Pengangkutan Laut, Bandung, Nuansa Aulia.

Simanjuntak, Mangisi, 2018, Konvensi PBB 1982 tentang Hukum Laut Makna \& Manfaat Bagi Bangsa Indonesia, Jakarta, Mitra Wacana Media.

Sood, Muhammad, 2019, Hukum Lingkungan Indonesia, Jakarta, Sinar Grafika.

Tsani Mohamad, Burhan, 1990, Hukum dan Hubungan Internasional, Cetakan Pertama, Yogyakarta, Liberty.

Wartini, Sri, 2019, Penegakan Hukum Lingkungan Internasional Peran Konsumen dan Hijau, Yogyakarta, UII Press.

Wijoyo, Suparto dan A'an Efendi, 2017, Hukum Lingkungan Internasional, Jakarta, Sinar Grafika.

\section{Sumber Lain :}

Kamus Besar Bahasa Indonesia

KUHD

PP Nomor 19 Tahun 1999 Tentang

Pengendalian Pencemaran dan/atau Perusakan Laut

UNCLOS 1982

UU Nomor 17 Tahun 1985 Tentang Pengesahan United Nations on the law of the sea ( Konvensi Perserikatan Bangsa-Bangsa tang hukum laut)

\section{INTERNET}

https://www.kompasiana.com/gunawan1412/5 910180152f9fd7d5f93257a/kasustumpahan-minyak-indonesiasingapuradalam-hukum-internasional?page=all (diakses pada tanggal 17 Agustus 2020 Pukul 13 : 00 WITA) 